\title{
PENGARUH PIJAT PUNGGUNG DENGAN MINYAK ESSENSIAL LEMON TERHADAP NYERI PUNGGUNG BAWAH PADA LANSIA
}

\section{The Effectiveness of Back Massage with Lemon Essential Oil on Nyeri punggung bawah in Elderly}

\author{
Tutut Putri Utami ${ }^{1}$, Sopian Halid ${ }^{2}, \mathrm{Hapipah}^{3}$, Irwan $\mathrm{Hadi}^{4}$, Istianah ${ }^{5}$, Baiq Nurainun Apriani Idris ${ }^{6}$ \\ ${ }^{1}$ Mahasiswa Sarjana Keperawatan,Stikes Yarsi Mataram,Mataram, NTB, Indonesia \\ 2,3,4,5 Program Studi S1 Keperawatan,Stikes Yarsi Mataram, Mataram, NTB, Indonesia \\ ${ }^{6}$ Program Studi Profesi Ners,Stikes Yarsi Mataram, Mataram, NTB, Indonesia \\ Korespondensi :pey.hapipah15@gmail.com
}

\begin{abstract}
ABSTRAK
Nyeri punggung bawah merupakan salah satu gangguan musculoskeletal akibat aktifitas yang kurang baik menyebabkan timbulnya rasa nyeri yang sering diderita oleh lansia. Salah satu manajemen nyeri non farmakologis dapat dilakukan dengan pijat punggung dengan minyak essensial lemon. Pijat punggung merupakan teknik memberikan tindakan pijat pada punggung dengan usapan secara perlahan. Tujuan penelitian ini untuk mengetahui pengaruh pijat punggung dengan minyak essensial lemon terhadap nyeri punggung bawah pada lansia di Balai Sosial Lanjut Usia Mandalika Mataram. Jenis penelitian ini adalah pre eksperimental dengan rancangan one group pretest-posttest design. Jumlah sampel sebanyak 17 orang yang dipilih berdasarkan teknik purposive sampling. Analisis data menggunakan analisis univariat dan bivariat. Berdasarkan analisis paired t-test menunjukkan bahwa melakukan pijat punggung dapat menurunkan skala nyeri punggung bawah pada lansia dengan nilai $\rho=0,000(<0,05)$. Dapat diambil kesimpulkan bahwa ada pengaruh pemberian pijat punggung dengan minyak essensial lemon terhadap skala nyeri punggung bawah pada lansia di Balai Sosial Lanjut Usia Mandalika. Berdasarkan hasil penelitian tersebut pijat punggung dengan minyak essensial lemon sebagai salah satu alternative intervensi keperawatan untuk mengurangi rasa nyeri punggung bawah.
\end{abstract}

Kata kunci: pijat, punggung, essensial, lemon, lansia.

\section{ABSTRACT}

Low back pain is a musculosceletal disorder due to poor activity which causes pains that are often suffered by the elderly. One of the non-pharmacological pain management can be done by back massage with lemon essential oil. Back massage is a technique to massage the back with gentle strokes. The purpose of this study was to determine the effect of back massage with lemon essential oil on low back pain in the elderly at the Mandalika Mataram Elderly Social Center. This type of research is pre-experimental with a one group pretest-posttest design. The number of samples of 17 people selected based on purposive sampling technique. Data analysis used univariate and bivariate analysis. Based on the paired t-test analysis, it shows that doing back massage can reduce the scale of low back pain in the elderly with $\rho$ value $0.000(<0.05$.) iT can be concluded that there is a significant effect of back massage with lemon essential oil on low bak pain scale in the elderly at the Mandalika Mataram Elderly Social Center. Based on the results of this study, back massage with lemon essential oil is an alternative nursing intervention to reduce low back pain.

Keywords: massage, back, essential, lemon, elderly. 
Tutut Putri Utami, dkk: Pengaruh Pijat Punggung Dengan Minyak Essensial Lemon Terhadap Nyeri Punggung Bawah Pada Lansia

\section{PENDAHULUAN}

Proses penuaan merupakan sebuah mekanisme perubahan anatomi dan fisiologi serta biokimia yang terjadi pada manusia seiring dengan bertambahnya usia. Pada lanjut usia (lansia), seluruh proses ini akan mengakibatkan fungsi dan kemampuan tubuh mengalami penurunan, sehingga mempengaruhi serangkaian aktifitas individu. Jumlah lansia di kawasan Asia Tenggara dilaporkan sebanyak $8 \%$ dari total populasi atau sekitar 142 juta jiwa. Pada tahun 2050 diperkirakan populasi lansia meningkat 3 kali lipat. Di Indonesia diperkirakan pada tahun 2020 jumlah lansia mencapai sekitar 80 juta jiwa (Kementerian Kesehatan RI, 2013).

Beberapa masalah kesehatan yang dialami lansia akibat penurunan fungsi tubuh dapat berupa permasalahan pada sistem muskuloskeletal. Diperikirakan 10-15\% kekuatan otot dapat hilang setiap minggu jika otot beristirahat sepenuhnya, dan sebanyak $5,5 \%$ dapat hilang setiap hari pada kondisi istirahat dan imobilitas sepenuhnya (Stanley, Beare, \& Patricia Gauntlett, 2006). Salah satu masalah fisik sehari-hari yang sering ditemukan pada lansia adalah nyeri punggung bawah (Bandiyah, 2009).

Prevalensi nyeri muskuloskeletal, termasuk nyeri pungguh bawah, dideskripsikan sebagai sebuah epidemik. Sekitar 80 persen dari populasi pernah menderita nyeri punggung bawah paling tidak sekali dalam hidupnya. Berdasarkan data yang di dapat di dunia bahwa persentase keparahan nyeri pungguh bawah pada laki-laki dan perempuan yaitu kategori berat $(48,32 \%$ dan $53,64 \%)$, lumpuh $(3,35 \%$ dan $8,68 \%)$, dan katagori minimal $(2,68 \%$ dan 2,64\%). Pada usia 40-45 tahun menunjukkan bahwa perempuan memiliki persentase lebih tinggi dari pada laki-laki dengan nyeri saat berjalan, duduk, tidur, dalam kehidupan sosial dan dalam aktivitasnya (Chawla, Schneck, \& Wheeler, 2018).

Dengan demikian semakin lanjut usia, maka semakin besar risiko terkenanya nyeri punggung bawah. Orang berusia lanjut terjadi penurunan fungsi-fungsi tubuhnya terutama tulangnya sehingga tidak lagi elastis seperti diwaktu muda. Data untuk jumlah penderita nyeri pungguh bawah di Indonesia belum diketahui secara pasti, namun diperkirakan penderita nyeri pungguh bawah di Indonesia bervariasi antara 7,6\% sampai $37 \%$ dari jumlah penduduk yang ada di Indonesia (Lailani, 2013). Studi pendahuluan yang dilakukan bertempat di Balai Sosial Lanjut Usia Mandalika Kota Mataram tahun 2018 bahwa dari 80 orang lansia di Balai Sosial Lanjut Usia Mandalika terdapat 30 orang yang mengaami nyeri punggung bawah.

Penanganan nyeri dapat dibantu dengan terapi non-farmakologi. Terdapat beberapa tehnik non-farmakologi seperti memberikan pijatan punggung dengan aromaterapi minyak esensial. Usapan dengan minyak essensial memberikan sensasi hangat dengan mengakibatkan dilatasi pada pembuluh darah lokal. Lansia yang diberikan terapi pijatan punggung mengalami penurunan nyeri dari intensitas sedang menjadi ringan (Kristanto \& Maliya, 2012). Lemon merupakan salah satu aromaterapi yang dapat membantu melancarkan sirkulasi tubuh. Zat yang terkandung dalam lemon adalah linalool yang berguna untuk menstabilkan sistem saraf sehingga dapat menimbulkan efek tenang bagi siapapun yang menghirupnya (Purwandari \& Sabrian, 2012). Berdasarkan uraian diatas, peneliti tertarik melakukan penelusuran lebih lanjut terhadap efek pijat punggung yang dikombinasikan dengan penggunaan aromaterapi lemon pada lansia dengan masalah nyeri punggung bawah.

\section{TUJUAN PENELITIAN}

Penelitian ini memiliki tujuan menganalisis pengaruh pijat punggung dengan minyak essensial lemon terhadap nyeri punggung bawah pada lansia di Balai Sosial Lanjut Usia Mandalika.

\section{METODE PENELITIAN}

\section{Desain}

Penelitian ini menggunakan rancangan penelitian metode pra eksperimental dengan pendekatan one group pretest - posttest.

\section{Populasi dan Sampel}

Populasi dalam penelitian ini adalah semua lansia yang mengalami nyeri pungguh bawah di Balai Sosial Lanjut Usia Mandalika sebanyak 30 orang. Sampel pada penelitian ditentukan dengan menggunakan sampel menggunakan rumus Frederer dengan teknik 
Tutut Putri Utami, dkk: Pengaruh Pijat Punggung Dengan Minyak Essensial Lemon Terhadap Nyeri Punggung Bawah Pada Lansia

sampling purposive. Jumlah sampel sebanyak 17 orang. Adapun kriteria inklusi subjek penelitian adalah lansia yang berusia 59-66 tahun; berjenis kelamin perempuan; lansia yang bersedia dilakukan pijat punggung; kesadaran composmentis dan dapat berkomunikasi dengan baik; tingkat nyeri sedang; tidak menggunakan anti nyeri selama penelitian. Sedangkan kriteria inklusidalam penelitian ini adalah lansia yang memiliki alergi jika diberi usapan minyak; lansia yang tidak dapat berkomunikasi dengan baik.

\section{Tempat dan Waktu Penelitian}

Penelitian dilaksanakan selama 4 minggu, bertempat di Balai Sosial Lanjut Usia Mandalika Kota Mataram.

\section{Instrumen dan Prosedur Pengukuran}

Pengumpulan data menggunakan kuisioner karakteristik responden dan lembar observasi pengukuran nyeri. Nyeri dukur menggunakan visual analog scale. Pengukuran nyeri dilakukan sebelum dan setelah diberikan terapi pijat punggung dengan minyak esensial lemon.

\section{Analisa Data}

Analisa data yang digunakan dalam penelitian ini adalah paired t-test.

\section{Intervensi}

Intervensi dilakukan dengan memberikan pijat punggung dengan minyak essensial lemon yang dilakukan sebanyak 2 kali seminggu pada pagi hari selama 4 minggu.

\section{HASIL PENELITIAN \\ Karakteristik Responden}

Tabel 1

Karakteristik Responden di Balai Sosial

\begin{tabular}{ccc}
\multicolumn{2}{c}{ Mandalika Mataram $(\mathrm{n}=17)$} \\
\hline Karakteristik & f & \% \\
\hline Usia & & \\
$60-74$ & 17 & 100 \\
$75-90$ & 0 & 0 \\
Jenis Kelamin & & \\
$\quad$ Laki-Laki & 0 & 0 \\
$\quad$ Perempuan & 0 & 0 \\
Pekerjaan & & \\
$\quad$ ART & 6 & 35,3 \\
$\quad$ Wiraswasta & 5 & 29,4
\end{tabular}

\begin{tabular}{lcc} 
Tidak Bekerja & 4 & 23,5 \\
Petani Nyeri & 2 & 11,8 \\
Lama & & \\
Pungguh Bawah & & \\
$1-2$ tahun & 12 & 70,6 \\
$<1$ tahun & 5 & 29,4 \\
\hline
\end{tabular}

Hasil analisis distribusi Frekuensi data karakteristik responden dapat dilihat bahwa usia responden penderita nyeri pungguh bawah yang terbanyak di usia 60-74 tahun sebanyak 17 responden $(100 \%)$. Jenis pekerjaan yang paling banyak yaitu ART sebanyak 6 responden $(35,3 \%)$. Lama menderita nyeri pungguh bawah yang paling banyak yaitu selama 1-2 tahun sebanyak 12 responden $(70,6 \%)$.

\section{Tabel 2}

Pengaruh Pijat Punggung dengan Minyak Esensial Lemon di Balai Sosial Mandalika Mataram Tahun $2019(n=17)$

\begin{tabular}{lccccc}
\hline \multicolumn{1}{c}{ Variabel } & f & \% & Mean & SD & $\begin{array}{c}\text { p- } \\
\text { value }\end{array}$ \\
\hline Pre Test & & & & & \\
Tidak Nyeri & 0 & 0 & & & \\
Nyeri Ringan & 4 & 23,5 & & & \\
Nyeri Sedang & 13 & 76,5 & 4,47 & 1,37 & \\
Nyeri Berat & 0 & 0 & & & \\
Sangat Berat & 0 & 0 & & & 0,000 \\
\hline Post Test & & & & & \\
Tidak Nyeri & 13 & 23,5 & & & \\
Nyeri Ringan & 4 & 76,5 & & & \\
Nyeri Sedang & 0 & 0 & 0,47 & 0,87 & \\
Nyeri Berat & 0 & 0 & & & \\
Sangat Berat & 0 & 0 & & & \\
\hline
\end{tabular}

Berdasarkan tabel 2 di atas hasil yang diperoleh adalah skala nyeri sedang sebanyak 13 responden $(76,5 \%)$ dan skala nyeri ringan sebanyak 4 responden $(23,5 \%)$ dengan rata-rata skala nyeri sebelum dilakukan pijat punggung dengan minyak essensial lemon adalah 4,47. Setelah dilakukan pijat punggung diperoleh data responden yang tidak nyeri sebanyak 13 responden $(76,5 \%)$ dan skala nyeri ringan sebanyak 4 responden $(23,5 \%)$ dengan rata-rata skala nyeri setelah dilakukan pijat punggung dengan minyak essensial lemon adalah 0,47. Perbedaan rata-rata skala nyeri sebelum dan sesudah intervensi pijat punggung dengan minyak essensial lemon yaitu 4,47 menurun menjadi 0,47 dengan dif mean 4 , dengan hasil 
Tutut Putri Utami, dkk: Pengaruh Pijat Punggung Dengan Minyak Essensial Lemon Terhadap Nyeri

Punggung Bawah Pada Lansia

statistic signifikan $\mathrm{p}$ value $=0,000(<0,05)$. Dari hasil statistik tersebut menunjukkan bahwa adanya pengaruh pijat punggung dengan minyak essensial lemon terhadap nyeri nyeri punggung bawah pada lansia.

\section{PEMBAHASAN}

\section{Karakteristik Responden}

Responden berdasarkan usia pada lansia di Balai Sosial Lanjut Usia Mandalika di dapatkan responden memiliki umur di atas 50 tahun dengan umur responden paling banyak 60-74 tahun yaitu sebanyak 17 responden $(100 \%)$. Usia merupakan faktor yang memperberat terjadinya nyeri punggung bawah, sehingga biasanya diderita oleh orang berusia lanjut karena penurunan fungsi-fungsi tubuhnya terutama tulangnya sehingga tidak lagi elastis seperti diwaktu muda. Hal ini sesuai dengan penelitian Nurlis, Bayhakki, \& Erika (2012), yang mengatakan bahwa resiko dari nyeri punggung bawah meningkat pada lansia yang semakin tua. Semakin bertambahnya umur, maka akan terjadi proses fibrosis dan klasifikasi pada tulang belakang berurutan dan saling berdekatan sehingga memudahkan timbulnya rasa nyeri pada daerah tulang belakang.

Penelitian Aprilia (2009), menemukan bahwa pasien nyeri pungguh bawah paling banyak terdapat pada usia $>54$ tahun karena adanya gangguan discus intervertebralis, kerusakan jaringan, terbentuk jaringan parut, pengurangan cairan sehingga menyebabkan stabilitas tubuh berkurang terutama pada bagian punggung. Hal ini terjadi karena pada umur setengah baya, kekuatan dan ketahanan otot mulai menurun sehingga risiko terjadi keluhan otot semakin meningkat (Tarwaka, 2014).

Distribusi responden berdasarkan jenis kelamin pada lansia di Balai Sosial Lanjut Usia Mandalika didapatkan responden secara keseluruhan perempuan (100\%). Sesuai dengan hasil penelitian Kurniasih (2013), menyatakan bahwa perempuan memiliki resiko lebih besar untuk menderita nyeri pungguh bawah dibandingkan laki-laki, menunjukkan bahwa respon nyeri lebih dirasakan oleh perempuan dikarenakan pada wanita terjadi menstruasi dan proses menopause yang menyebabkan kepadatan tulang berkurang akibat penurunan hormone esterogen.
Penelitian Hendy, Untung, \& Lantjip (2010), yang menyebutkan bahwa wanita 2 kali lebih besar dibandingkan laki-laki dikarenakan pada wanita di pengaruhi oleh obesitas, prevalensi nyeri pungguh bawah pada wanita $60,98 \%$ dan pada laki-laki 39,02\%. Shiri, Karppinen, Leino-Arjas, Solovieva, \& ViikariJuntura (2009), menyatakan bahwa nyeri punggung bawah lebih sering terjadi pada wanita dibandingkan dengan laki-laki karena dipengaruhi oleh obesitas.

Distribusi responden berdasarkan lama menderita nyeri pungguh bawah pada lansia di Balai Sosial Lanjut Usia Mandalika didapatkan sebanyak 12 responden $(70,6)$ telah menderita nyeri pungguh bawah selama 1-2 tahun dan 5 responden $(29,4)$ telah menderita nyeri pungguh bawah selama kurang dari 1 tahun. Beckman, Waern, Gustafson, \& Skoog (2008), menemukan bahwa penderita nyeri punggung yang berkelanjutan selama 12 minggu lebih sulit untuk sembuh. Hal ini dikarenakan semakin lama responden mengalami nyeri dapat merubah pemikiran dan perilaku pasien terhadap nyeri. Pemikiran pasien tentang nyeri mengakibatkan pasien dapat merasa lebih sensitif terhadap rasa nyeri, merasa sakit dan takut bergerak.

Pengaruh Pijat Punggung dengan Minyak Esensial Lemon terhadap Nyeri Punggung Bawah pada Lansia

Hasil penelitian menunjukkan bahwa skala nyeri sebelum melakukan pijat punggung dengan minyak essensial lemon didapatkan skala nyeri sedang sebanyak 13 responden $(76,5 \%)$ dan skala nyeri ringan sebanyak 4 responden $(23,5 \%)$ dengan rata-rata 4,47 . Sedangkan skala nyeri sesudah dilakukan pijat punggung dengan minyak essensial lemon didapatkan tidak nyeri sebanyak 13 responden $(76,5 \%)$ dan skala nyeri ringan sebanyak 4 responden $(23,5 \%)$ dengan rata-rata 0,47 .Hasil uji hipotesis diperoleh nilai $p=0,000(<0,05)$.

Berdasarkan hasil diatas dapat terlihat ada perbedaan persepsi nyeri meskipun stimulusnya sama. Manajemen nyeri dapat diatasi dengan terapi non-farmakologis menggunakan pijat punggung. Penyebab yang paling sering ditemukan yang dapat mengakibatkan nyeri pungguh bawah adalah kekakuan dan spasme otot punggung oleh karena aktivitas tubuh yang kurang baik serta 
Tutut Putri Utami, dkk: Pengaruh Pijat Punggung Dengan Minyak Essensial Lemon Terhadap Nyeri

Punggung Bawah Pada Lansia

tegangnya postur tubuh (Potter, Perry, Stockert, \& Hall, 2012).

Penelitian yang dilakukan oleh Achjar (2012), dimana tingkat nyeri sebelum diberikan back massage dengan kategori nyeri sedang sebanyak 22 orang, nyeri ringan 5 orang. Tingkat nyeri pungguh bawah setelah diberikan back mssage dengan kategori nyeri ringan sebanyak 23 orang, tidak nyeri sebanyak 5 orang dan nyeri sedang dua orang. Penelitian diatas menunjukkan bahwa back massage efektif untuk menurunkan tingkat nyeri pungguh bawah. Sejalan dengan penelitian Primayanthi, Azis, \& Puspita (2016) menemukan bahwa rata-rata nyeri sebelum diberikan terapi adalah 4,83 dan skala nyeri yang paling banyak dialami oleh responden adalah skala nyeri 5 sedangkan setelah diberikan terapi didapatkan bahwa rata-rata nyeri setelah di berikan terapi adalah 2,67 dan skala nyeri yang paling banyak dialami oleh responden adalah skala nyeri 2 , menunjukkan bahwa adanya perbedaan signifikan antara nyeri sebelum dan sesudah diberikan terapi slow stroke back massage dengan minyak essensial.

Hasil dari observasi yang dilakukan, diketahui penurunan skala nyeri disebabkan oleh pijat punggung dengan minyak essensial lemon, dimana responden teratur melakukan pijat punggung dengan minyak essensial lemon yang dilakukan 2 kali seminggu pada pagi hari selama 4 minggu dengan durasi 10 menit. Berdasarkan penjelasan diatas dapat disimpulkan bahwa kepatuhan melakukan pijat punggung dengan minyak essensial lemon dapat menurunkan skala nyeri pungguh bawah, mereka menganggap dengan rutin melakukan pijat punggung dapat menurunkan skala nyeri pungguh bawah karena sebelumnya skala nyeri pungguh bawah masih tinggi. Pijat punggung adalah stimulasi kulit yang dilakukan untuk menghilangkan nyeri, bekerja dengan cara mendorong pelepasan endorphin, sehingga memblok transmisi stimulus nyeri (Potter et al., 2012).

\section{KESIMPULAN \\ Implikasi}

Berdasarkan hasil penelitian dan pengumpulan data yang telah dilakukan maka penelitian ini mempunyai kesimpulan bahwa terdapat pengaruh pijat punggung dengan minyak essensial lemon terhadap nyeri punggung bawah pada lansia. Hasil penelitian ini memberikan peluang bagi perkembangan ilmu keperawatan untuk mengembangkan intervensi keperawatan sesuai evidencebased practice. Temuan pada penelitian ini dapat digunakan sebagai data dasar keilmuan keperawatan secara khusus tentang intervensi komplementer dalam menurunkan nyeri pada lansia dengan nyeri punggung bawah.

\section{Keterbatasan}

Penelitian ini hanya melibatkan responden wanita yang disebabkan oleh minimnya jumlah responden laki-laki yang mengalami nyeri punggung bawah di lokasi penelitian. Diperlukan penelitian lebih lanjut dengan melibatkan responden dengan jenis kelamin laki-laki pada populasi yang lebih luas.

\section{DAFTAR PUSTAKA}

Achjar, K. A. H. (2012). Terapi Musik Dan Massase Punggung Terhadap Intensitas Nyeri Sendi Lansia. Gema Keperawatan.

Aprilia, M. (2009). Tinjauan Faktor Risiko Ergonomi Terkait Keluhan Musculoskeletal Disorders (MSDs) Pada Pekerja Konstruksi PT. Waskita Karya di Proyek Fasilitas Rekreasi dan Olahraga Boker Ciracas Tahun 2009. Universitas Indonesia.

Bandiyah, S. (2009). Lanjut Usia dan keperawatan Gerontik. Yogyakarta: Salemba Medika.

Beckman, N., Waern, M., Gustafson, D., \& Skoog, I. (2008). Secular trends in self reported sexual activity and satisfaction in Swedish 70 year olds: Cross sectional survey of four populations, 1971-2001. $B M J, 337(7662), 151-154$.

Chawla, J., Schneck, M. J., \& Wheeler, A. H. (2018). Low Back Pain and Sciatica: Overview, Pathophysiology, Characteristics of Pain-Sensitive Structures. Retrieved from https://emedicine.medscape.com/article/11 44130-overview

Hendy, P., Untung, G., \& Lantjip, R. (2010). Overweight Sebagai Faktor Resiko Low Back Pain Pada Pasien Poli Saraf RSUD Prof. DR. Margono Soekarjo Purwokerto. Mandala of Health, 4(1), 26-32. 
Tutut Putri Utami, dkk: Pengaruh Pijat Punggung Dengan Minyak Essensial Lemon Terhadap Nyeri Punggung Bawah Pada Lansia

Kementerian Kesehatan RI. (2013). Populasi Lansia Diperkirakan Terus Meningkat Hingga Tahun 2020. Retrieved from http://www.p2ptm.kemkes.go.id/kegiatanp2ptm/aceh/populasi-lansia-diperkirakanterus-meningkat-hingga-tahun-2020

Kristanto, T., \& Maliya, A. (2012). Pengaruh Terapi Back massage Terhadap Intensitas Nyeri Reumatik Pada Lansia di Wilayah Puskesmas Pembantu Karang Asem. Universitas Muhammadiyah Surakarta.

Kurniasih, E. (2013). Penambahan Terapi Latihan MC . Kenzie pada Intervensi Short Wave Diathermy (SWD), Trancutaneus Electrical Stimulation (TENS) dan Massage Dapat Lebih Menurunkan Nyeri Pinggang pada Kasus Low Back Pain. Majalah Ilmiah Fisioterapi Indonesia (MIFI)., 1-8.

Lailani, T. M. (2013). Hubungan Antara Peningkatan Indeks Massa Tubuh Dengan Kejadian Nyeri Punggung Bawah Pada Pasien Rawat Jalan di Poliklinik Saraf RSUD Dokter Soedarso Pontianak. Universitas Tanjungpura.

Nurlis, E., Bayhakki, \& Erika. (2012). Pengaruh Terapi Dingin Ice Massage Terhadap Perubahan Intensitas Nyeri Pada Penderita Low Back Pain. Jurnal Ners Indonesia, 2(2), 185-191.

Potter, P. A., Perry, A. G., Stockert, P. A., \& Hall, A. M. (2012). Fundamentals of Nursing (8th ed.). St. Louis Missouri: Mosby, Inc.

Primayanthi, A. A. A., Azis, A., \& Puspita, L. M. (2016). Pengaruh Terapi Slow Stroke Back Massage Dengan Minyak Essensial Lavender Terhadap Penurunan Intensitas Nyeri Low Back Pain. COPING NERS (Community of Publishing in Nursing), 4(1), 36-40.

Purwandari, F., \& Sabrian, F. (2012). Efektifitas Terapi Aroma Lemon Terhadap Penurunan Skala Nyeri Pada Pasien Post Laparatomi. Jurnal Online Mahasiswa Program Studi Ilmu Keperawatan Universitas Riau, 1, 1-6.

Shiri, R., Karppinen, J., Leino-Arjas, P., Solovieva, S., \& Viikari-Juntura, E. (2009). The association between obesity and low back pain: A meta-analysis. American Journal of Epidemiology, 171(2), 135-154.
Stanley, M., Beare, \& Patricia Gauntlett. (2006). Buku Ajar Keperawatan Gerontik (2nd ed.). Jakarta: EGC.

Tarwaka. (2014). Ergonomi Industri Revisi (II). Solo: Harapan Press Solo. 